\title{
Potential Market Willingness to Pay Through Edutourism Plan at CV. Damarayu Malang District
}

\author{
Like Mutiaristi $^{1 *}$, Ratya Anindita ${ }^{2}$, Condro Puspo Nugroho ${ }^{2}$ \\ Department of Socio Economics, Faculty of Agriculture, Brawijaya University, Jl. Veteran, Malang \\ 65145, Indonesia
}

Received: 17 July 2017; Revised: 13 October 2017; Accepted: 1 December 2017

\begin{abstract}
Edutourism is a necessity for kindergarten school, and enteprise can develop edutourism for kindergarten school as their potential market. This fact is crucial to observe to encounter potential market with enteprise that can supply their needs and both can get profit from the edutourism. By that background, this research are going to find valuation of the edutourism plan by potential market willingness to pay (WTP), to know factors that influence potential market WTP and to know potential market segmentation that declare willing to pay the edutourism. This research uses quantitative approach, analyzed by contingent valuation method and logistic regression analysis. The potential market in this research are kindergarten school in Pakisaji sub-district that have outingclass program. The finding revealed that economic value of the edutourism is more than the price target. Factors that influence potential market WTP are teachers education background, school fee per month, and ability to pay. Segmentation of the edutourism plan are kindergarten school with standard teacher's education background in bachelor degree, categorized in low price school fee and already have ability to pay the edutourism.
\end{abstract}

Keywords: edutourism; market; willingness; valuation

\section{How to cite:}

Mutiaristi, L., Anindita, R., Nugroho, C. P. (2017). Potential Market Willingness To Pay Through Edutourism Plan at CV. Darmayu Malang District. HABITAT, 28(3), 83-90. https://doi.org./10.21776/ub.habitat.2017.028.3.12

\section{Introduction}

The concept of edutourism has developed in the past few years and it can be used as the alternative to improve the company's income including Agribusiness Company. (Ojo, Yusofu 2013; and Rezapouraghdam, Shahgerdi, Kahrizi 2015) state that edutourism has attracted the researchers' attention these past few years due to its contribution to the economic improvement. Taleb Rifai in UNWTO (2017) states the same thing, he agrees that tourism sector is able to contribute to the economy and employment. Another benefit is the knowledge given by the edutourism. According to Sherri (2017), edutourism can be presented in various types of learning including agribusiness company visit because the most important part of edutourism is the essence of life learning that can be given. Ritchie et al (2003) mention that edutourism will be identified based on the school market

${ }^{*}$ Corresponding Author:

E-mail: like.mutiaristi@gmail.com segment. Meanwhile, the potential market to get the benefit of edutourism is Kindergarten. This is because the availability of outingclass as part of learning by playing activity outside the school environment to develop the children's intelligence. The presence of outingclass in Kindergarten can be synergized with edutourism provided by the agribusiness company. For example, CV. Damarayu which is part of the oyster mushroom company. If the Kindergarten in Pakisaji wants to do the tour, they can choose $\mathrm{CV}$. Damarayu as the edutourism destination. Thus, both parties will have mutual benefit. However, CV. Damarayu has to set the affordable price in accordance with the willingness of Kindergarten to pay the edutourism service.

According (Carson, 2000; Hoyos \& Mariel, 2010; Charusiri, Tuntates, \& Choiejit, 2015) the willingness of the potential market to pay can be determined by using contingent valuation. The analyzed value of the willingness of the potential market to pay will be further 
analyzed using logistic regression to determine the factors affecting the willingness to use edutourism. Foreit \& Foreit (2004) add that the analysis can be used to determine the number and characteristics of the potential market willing to use edutourism service at the offered price level. Hence, the researcher will know the segmentation of appropriate potential market for edutourism through analysis and logistic. Based on the background of this research, the purposes of the research are: 1.) Obtaining edutourism value based on the potential market willingness to pay; 2.) Determining the factors influencing the willingness of potential market to pay the edutourism service; and 3.) Determining the segmentation of potential market willing to use edutourism service. The use of contingent valuation and logistic regression is expected to give benefit to the company to improve the income by determining the economic value and segmentation of edutourism. Furthermore, edutourism can be realized to fulfill the needs of Kindergarten students in Pakisaji Sub-District.

\section{Research Methods}

\subsection{Method of Determination of Location and Time of Research}

The research was conducted on 26 Kindergartens in the Pakisaji Sub-District Malang Regency, East Java. The determination of location is based on the consideration as follows: 1.) Kindergarten as a potential market for edutourism plan; 2.) Kindergarten in Pakisaji Sub-District is chosen as the research site because the researcher used edutourism plan of CV. Damarayu located in Pakisaji area and specific location is used to get the appropriate economic value from edutourism of $\mathrm{CV}$. Damarayu; 3.) The location is determined based on the researcher's needs for the characteristics of the respondents who are relatively homogeneous. Thus, the researcher limits the respondents based on the cluster in the Pakisaji Sub-District. Data collection in this research was conducted in May 2017.

\subsection{Sampling Method}

The sample used in this research is 26 teachers from 26 Kindergarten in Pakisaji SubDistrict. The determination of sampling is done through purposive based on these considerations: 1.) The respondents are Kindergarten teachers because teacher has the main role in deciding whether they will use edutourism or not; 2.)
Researchers only collect information from 1 teacher of each Kindergarten. The reason is that most of Kindergarten in Pakisaji only have 30-4 teachers averagely and they tend to give the homogeneous response.

\subsection{Data Collection Method}

In this research, the primary data is obtained through observation and interview with the respondents. The interview is conducted in a structured manner using questionnaire. Meanwhile, the secondary data is used by the researcher to know the name and full address of every kindergarten unit.

\subsection{Data Analysis Method}

The data obtained by the researcher will be analyzed using methods of analysis as follows:

a. Descriptive Statistics Test

In this analysis, the researcher intends to give description or characteristics of the Kindergarten and respondents. Hence, the researcher uses central statistical test tool or descriptive statistics. According to Nasoetion \& Barizi (1980), the typical description of the diversity of data needs should be compiled into frequency list form. The nature of data diversity is very important and related to hypothesis testing. Thus, the research uses descriptive statistics using frequency list.

\section{b. Contingent Valuation}

According to Carson (2000), contingent valuation is an economic valuation method done by asking directly to respondents regarding their willingness to pay something. The questions in this research use the auction value game which is one of the techniques of asking the respondents related to the value of willingness to pay using specific value of particular auction. The stages in the analyses are as follows:

1) Identifying the service to be analyzed.

2) Creating hypothetical scenario construction.

Pearce et al (2006) state that the proposed question and scenario will greatly affect the output. Essential elements at this stage are the description of the developed market namely edutourism plan in CV. Damarayu; the description of the impact of the scenarios offered; and monetary elicitation.

3) Value Estimation of Edutourism

The primary data that have been obtained are analyzed based on the overall average WTP 
value. According to Hanley \& Spash (1993), the average WTP formula is:

$\mathrm{EWTP}=\frac{\sum \mathrm{WTP} \cdot \mathrm{X} i}{N}$

Where:

EWTP = average estimation of WTP $(I D R)$

WTP.Xi

$=$ WTP value of each respondent $(I D R)$

$N=$ number of respondents (person)

Then count up the data by multiplying the average value of the offer with the intended population. The formula used in this research is:

TWTP $=$ EWTP. N $i$

Where:

TWTP = Number of WTP (IDR)

EWTP = Average of WTP (IDR)

$\mathrm{N} i=$ Population (person)

c. Logistic Regression Analysis

Logistic regression is used to determine the effect of each variable on the willingness to pay. In this research, the variable of willingness to pay is dichotomy variable with the value of 0 for not willing to pay and 1 for willing to pay. Nachrowi \& Usman (2002) and Hendayana (2013) state that the method to get the estimation of dichotomous dependent variable is logistic regression. While the logistic regression analysis model used by the researcher is as follows:

$$
\begin{aligned}
\operatorname{Ln}\left(\frac{P_{i}}{1-P_{i}}\right) & =\beta_{0}+\beta_{1} \mathrm{PDDKN}+\beta_{2} \mathrm{SPP}+ \\
& \beta_{3} \mathrm{ATP}+\beta_{4} \mathrm{TC}+\varepsilon \ldots \ldots \ldots \ldots \ldots
\end{aligned}
$$

Where:

$\mathrm{Pi} \quad$ : Probability of respondents willing to use edutourism

$1-P i \quad$ : Probability of respondents not willing to use edutourism

$\beta_{0} \quad:$ Intercept

$\beta_{1}, \beta_{2}, \beta_{3} \quad:$ Regression coefficient

PDDKN : Education level of the respondents

SPP : Contribution of Educational Development (IDR/month/student)

ATP : Budget travel allocation (IDR/student)

TC : Transportation travel cost (IDR/siswa)

$\varepsilon \quad:$ Error

According to Nachrowi \& Usman (2002) and Gujarati \& Porter (2012), the testing of model significance and parameter on logistics function consist of G Test and Wald Test.
1) G Test

$G$ Test is used to test the existence of the influence of independent variable in the model simultaneously on the dependent variable. According to Nachrowi \& Usman (2002), G test statistics is defined as follows:

$G=-2 \operatorname{Ln}\left(\frac{\mathrm{L}_{0}}{L_{1}}\right)$

Where:

$\mathrm{L}_{0}$ : Likelihood without explanatory variables

$L_{1}$ : Likelihood with explanatory variables

2) Wald Test

According to Nachrowi \& Usman (2002), Wald test is a significance test of each partial coefficient parameter. Wald test statistic used in this research is as follows:

$W=\left(\frac{\widehat{\beta}}{\operatorname{SE}\left(\widehat{\beta}_{i}\right)}\right)^{2}$

Where:

$\hat{\beta} \quad$ : estimator $\beta_{i}$ $S E\left(\hat{\beta}_{i}\right)$ : standard error estimator from $\beta_{i}(1,2,3 \ldots n)$

3) Estimated Marginal Effect

According to Gujarati \& Porter (2009), calculating the marginal effect is done to find out the possibility of the rate change of each independent variable on the WTP variable. According to Williams \& Dame (2017), marginal effect can be calculated by the following formula:

$M E=P\left(Y=1 \mid X_{i}\right) \times P\left(Y=0 \mid X_{i}\right) \times \beta_{i}$

Where:

$\mathrm{Y} \quad$ : willingness to pay

$i \quad: 1,2,3,4 \ldots$

$X_{i} \quad: i$-independent variable

$P\left(Y=1 \mid X_{i}\right):$ probability of occurrence $\mathrm{Y}=1$ on $\mathrm{X} i$

$P\left(Y=0 \mid X_{i}\right):$ probability of occurrence $\mathrm{Y}=0$ on $\mathrm{X} i$

$\beta_{i} \quad:$ the coefficient of the i- parameter

\section{Results and Discussion}

\subsection{Characteristics of Respondents}

\subsubsection{Respondents Education Level}

The education level of the Kindergarten teachers is important because the teachers have a dominant role in giving the consideration to use the edutourism or not. The Kindergarten teachers' consideration is expected to have the relationship with their education level. Based on the data collected on the education level of the 
Kindergarten teachers, most of their education background is Undergraduate. The respondents with Senior High School (SMA) education level are 4 people or equivalent to $15.4 \%$. Meanwhile, respondents with Undergraduate (S1) are 22 people or equivalent to $80.8 \%$ of the overall respondents. The remaining $3.8 \%$ respondents are Graduate (S2) as their education level. The characteristics of the educational background of the respondents are presented in Table 1.

Table 1. Distribution of Frequency Based on Respondent Education Level

\begin{tabular}{cccc}
\hline No. & Education & $\boldsymbol{\Sigma}$ Sample (person) & $\boldsymbol{\Sigma}$ Sample (\%) \\
\hline 1. & Senior High School & 4 & 15.40 \\
2. & Graduate & 21 & 80.80 \\
3. & Undergraduate & 1 & 3.80 \\
\hline & Total & 26 & 100.00 \\
\hline
\end{tabular}

\subsection{Analysis of Value of Willingness to Pay}

This research uses contingent valuation approach to determine the value of potential market willingness to pay for using edutourism. The results of analysis on the respondents' willingness to pay are obtained through the stages in the implementation of contingent valuation as follows:

\subsubsection{Identification of Service Items}

The service product to be offered is edutourism. This is based on the consideration of assets that have been owned by the related company namely the oyster mushroom cultivation field that can be used as the edutourism location. Another consideration is that edutourism program or commonly called as outingclass by most of the Kindergartens. This program is usually conducted one or twice a year. Based on this consideration to meet the potential market needs of Kindergarten and increase the income of the company, edutourism becomes a service product that will be offered.

\subsubsection{Hypothetic Market Scenario}

The researcher offers the questions related to the existence of tourism activity of each Kindergarten (TK). Then, the researcher explains about the oyster mushroom edutourism plan of CV. Damarayu located in Soneta Sub-village Sonotengah Malang Regency. The illustration of the plan includes close location with most of the Kindergartens in Pakisaji Sub-District, facilities offered by CV. Damarayu, and benefits for the user. The facilities offered are education on the oyster mushroom using games and interactive video for children, the practice of making baglog mushroom until harvesting in an interesting way, each child will get a unique souvenir of baglog oyster mushroom. The lesson learned in the site can be applied directly at home by keeping the baglog humidity, noting the development of mushroom on the balog package, and harvesting the mushroom. It is expected that the children will learn and understand about oyster mushroom easily by using the souvenir. Furthermore, giving responsibility to the children to keep and take care the plant. Price estimation offered to the respondents is based on the minimum and maximum price estimation from the references of tourism sites. In addition, the price estimation is based on the company operating cost. Another benefit of edutourism is increasing the child's knowledge related to plan and environment.

\subsubsection{Monetary Elicitation with Bid Value}

This research uses the auction game method to find out the value of respondent's willingness to pay for edutourism offered. The value of the auction used in this research is based on the offered facility and reference of tourism sites that have been used by the respondents. Furthermore, the auction value is also determined based on the estimated price of edutourism, which is IDR $10,000.00$. So the auction values used in this research are IDR 15,000.00; IDR 25,000.00; and IDR 35,000.00.

\subsubsection{Estimated Value of Willingness to Pay}

1) Average Value of Willingness to Pay

The estimation of the average value of respondents' willingness to pay for the oyster mushroom edutourism is based on the ratio of the total value of willingness to pay given by the respondents with the total number of group of kindergarten students in Pakisaji Sub-District. Based on the calculation, the average value of the Kindergarten willingness to pay for oyster mushroom edutourism is IDR 21,923.00 per person. Thus, the company may set the tariff of IDR 21,923.00 in accordance with the average willingness to pay provided by the respondents. The detail of the data on the willingness to pay of each respondent is presented in Table 2 . 
Table 2. Average Value of WTP

\begin{tabular}{cccccc}
\hline No. Willingness to Pay (IDR) & $\begin{array}{c}\text { Percentage } \\
\Sigma \text { Sample } \\
(\boldsymbol{\%})\end{array}$ & $\begin{array}{c}\boldsymbol{\Sigma} \text { Sample } \\
\text { (person) }\end{array}$ & Student (person) & $\begin{array}{c}\text { EWTP } \\
\text { (IDR per person) }\end{array}$ \\
\hline 1. & 15000.00 & 50.00 & 13 & 932 & $7,500.00$ \\
\hline 2. & $25,000.00$ & 30.77 & 8 & 573 & $7,692.00$ \\
\hline 3. & $35,000.00$ & 19.23 & 5 & 358 & $6,731.00$ \\
\hline & Total & 100.00 & 26 & 1,863 & $21,923.00$ \\
\hline
\end{tabular}

2) Total Value of Willingness to Pay

The total value of respondents' willingness to pay is obtained based on the estimated average value of respondents' willingness to pay multiplied by the population. If the average of the estimated value of potential market willingness to pay is IDR 21,923.00 per person, then the total estimated value of willingness to pay edutourism is IDR 40,842,549.00 for a group with the number of 1,863 students in Pakisaji SubDistrict. This is the total value obtained by the company if they can optimize the edutourism. Based on the survey of willingness to pay, it is found that the potential market willingness to use edutourism is very big. It is proved by the statements made by 26 Kindergartens that are willing to use edutourism if it's realized. Although each of it will have different price range between IDR 15,000.00; IDR 25,000.00; IDR 35,000.00. Furthermore, the value from the survey on the potential market willingness to pay is larger than the estimated tariff that will be applied by the company. The value from the survey on the potential market willingness to pay is IDR 21,923.00 while the tariff set out by the company is IDR $10,000.00$ per student.

Table 3. Aggregated Analysis of Total Value of the Willingness to Pay

\begin{tabular}{cccc}
\hline No & Willingness to Pay (IDR) & Population (person) & $\begin{array}{c}\text { TWTP } \\
\text { (IDR per person) }\end{array}$ \\
\hline $\mathbf{1}$ & $15,000.00$ & 932 & $13,972,500.00$ \\
$\mathbf{2}$ & $25,000.00$ & 573 & $14,331,128.00$ \\
\hline $\mathbf{3}$ & $35,000.00$ & 358 & $12,538,922.00$ \\
\hline & Total & 1,863 & $40,842,549.00$ \\
\hline
\end{tabular}

\subsection{Analysis of Factors Affecting the Willingness to Pay}

$$
\begin{aligned}
& \operatorname{Ln}\left(\frac{P_{i}}{1-P_{i}}\right)=-59.93+2.77 \mathrm{PDDKN}-0.11 \mathrm{SPP}+ \\
& 0.070 \mathrm{ATP}+0.02 \mathrm{TC}+\mathrm{e} \ldots \ldots \ldots \ldots \ldots \ldots \ldots \ldots \ldots \ldots \ldots \ldots \ldots \ldots \ldots \ldots \ldots \ldots \ldots \ldots \ldots \ldots
\end{aligned}
$$

analysis obtained the regression equation as follows:

\begin{tabular}{|c|c|c|c|c|}
\hline \multicolumn{5}{|c|}{ Model Summary } \\
\hline Prob > chi-square & & & & 0.0002 \\
\hline Pseudo R-square & & & & 0.6159 \\
\hline Log Likelihood & & & & -6.9219 \\
\hline Variable in equation & Coef. & $P>|\mathrm{z}|$ & Odds Ratio & Marginal Effect \\
\hline PDDKN & 2.77 & $0.03^{*}$ & 16.1 & 0.69349 \\
\hline SPP & -0.11 & $0.03 *$ & 0.89 & -0.1297 \\
\hline ATP & 0.07 & $0.06^{*}$ & 1.07 & 0.01751 \\
\hline TC & 0.02 & 0.55 & 1.02 & 0.00579 \\
\hline Coef. & -59.93 & 0.03 & - & - \\
\hline
\end{tabular}

Table 4. Logistic Regression Analysis

$*=$ significant at the level of $10 \%$

The regression equation shows the value Prob > chi ${ }^{2}$ of 0.0002 which can be interpreted that the model used in the analysis is statistically

significant because the value Prob $>c h i^{2}<0.1$. Based on the value of pseudo R2, it is found that the independent variable simultaneously explains 
the dependent variable amounted to $62 \%$ and the remaining $38 \%$ is explained by other factors outside of this model. Based on the result of Wald test, there are three factors affecting the potential market WTP significantly which are education,Educational Management Contribution (SPP) and the allocation of tourism budget of Kindergarten. Meanwhile, the travel cost factor does not have a significant influence on the WTP at the significance level of $10 \%$.

Logistic regression estimation is used through marginal effect calculation to know the possibility of the change rate of each independent on the dependent variable. Based on the educational coefficient of 0.69349 , it can be stated that respondents with the educational background higher than Senior High School have the probability of willingness to use edutourism equal to $69 \%$. This is in accordance with the research hypothesis because the respondents with higher educational background have more information related to the edutourism. The willingness to use edutourism will decrease by $12 \%$ if the Educational Management Contribution (SPP) variable increases by $1 \%$. This can happen because the Kindergarten with high Educational Management Contribution (SPP) tends to choose other edutourism with more facilities even when this kind of tourism offer more expensive price. In ATP coefficient it is known that if the ATP increase by $1 \%$ then the probability of the respondents' willingness to use edutourism will increase by $1.7 \%$. This is in accordance with the research hypothesis because each Kindergarten has its own large planning and allocation for their edutourism. The larger the
ATP of the Kindergarten for edutourism, the larger their willingness to use edutourism. Similarly, the TC coefficient shows that the increase of $\mathrm{TC}$ by $1 \%$ will increase the probability of the sample's willingness to use edutourism by $0.5 \%$. The result of marginal effects on TC variables are not consistent with the hypothesis. The reason is that most kindergartens with high spending habit for transportation tends to be more willing to use edutourism in Pakisaji due to cheaper price reason

\subsection{Potential Market Segmentation Analysis}

\subsubsection{Segmentation Based on the Kindergarten Teacher Education \\ Most of the Kindergarten teachers in} Pakisaji Sub-District are Undergraduate (S1) as their educational background. The tendency is that the teachers with the Undergraduate educational background will have a larger percentage of willingness to use edutourism rather than the teachers with Senior High School as their educational background. Meanwhile, the teachers with Graduate (S2) as their educational background are more difficult to be analyzed. The reason is that only one respondent from the total of 26 respondents who is Graduate (S2). Hence, the researcher cannot state directly if the teachers with Graduate (S2) educational background tend to be more willing or not in overall. Based on the results of descriptive statistic and logistic regression, it can be stated that segmentation of potential market is the Kindergarten with most of the teachers are Undergraduate (S1).

Table 5. Distribution of Frequency Based on Respondents Education

\begin{tabular}{ccccccc}
\hline No. & Education & $\begin{array}{c}\boldsymbol{\Sigma} \text { Sample } \\
\text { (person) }\end{array}$ & $\begin{array}{c}\text { Percentage } \boldsymbol{\Sigma} \\
\text { Sample (\%) }\end{array}$ & $\begin{array}{c}\text { Willingness } \\
\text { Percentage (\%) }\end{array}$ & $\begin{array}{c}\text { Unwillingness } \\
\text { Percentage (\%) }\end{array}$ & $\begin{array}{c}\text { TOTAL } \\
(\%)\end{array}$ \\
\hline 1. & SMA & 4 & 15.40 & 00.00 & 100.00 & 100.00 \\
2. & S1 & 21 & 80.80 & 68.00 & 32.00 & 100.00 \\
3. & S2 & 1 & 3.80 & 00.00 & 100.00 & 100.00 \\
\hline & Total & 26 & 100.00 & - & - & - \\
\hline
\end{tabular}

\subsubsection{Segmentation Based on Kindergarten Educational Management Contribution (SPP)}

The characteristics of the potential market are important to find out as the reference for the company in determining their market segment. Based on the collected data, it is found that most of Kindergarten (TK) in Pakisaji Sub-District have low Educational Management Contribution
(SPP). Furthermore, $54.17 \%$ of the total Kindergarten with low Educational Management Contribution are willing to use edutourism. The deviation occurs in 2 other kindergartens with Educational Management Contribution amounted to IDR 70,000.00. These two Kindergartens are not willing to use edutourism because they did not plan the tour program in 2017. Meanwhile, the remaining Kindergartens with Educational 
Management Contribution amounted to IDR $150,000.00$ have a tendency to use other edutourism with more facilities and higher cost. Based on the results obtained, the company can choose the kindergarten with low Educational Management Contribution as the target. The reason is that this kind of kindergarten has a greater tendency to use edutourism. The characteristics of Kindergarten Educational Management Contribution per month are presented in Table 6. Based on the research results, it is found that the potential market segmentation is the kindergarten with low Educational Management Contribution<IDR $60,000.00$ per student per month.

Table 6. Frequency Distribution Based on the Kindergarten Educational Management Contribution

\begin{tabular}{cccccc}
\hline $\begin{array}{c}\text { Educational } \\
\text { Management } \\
\text { Contribution } \\
\text { Category }\end{array}$ & $\begin{array}{c}\text { Educational } \\
\text { Management } \\
\text { Contribution } \\
(\text { IDR/month) }\end{array}$ & $\begin{array}{c}\Sigma \text { Sample (per } \\
\text { Kindergarten) }\end{array}$ & $\begin{array}{c}\text { Willingness } \\
\text { Percentage } \\
(\boldsymbol{\%})\end{array}$ & $\begin{array}{c}\text { Unwillingness } \\
\text { Percentage } \\
(\boldsymbol{\%})\end{array}$ & Total (\%) \\
\hline Low & $<60,000$ & 24 & 54.17 & 45.83 & 100.00 \\
Medium & $61,000-105,000$ & 1 & 0.00 & 100.00 & 100.00 \\
High & $>106,000$ & 1 & 0.00 & 100.00 & 100.00 \\
\hline \multicolumn{2}{c}{ Total } & 26 & - & - & - \\
\hline
\end{tabular}

\subsubsection{Segmentation Based on Edutourism} Budget Allocation of the Kindergarten

Potential market segmentation can also be determined based on the edutourism budget allocation. Based on the obtained results, it is found that the Kindergarten with edutourism budget allocation is the potential market segmentation for edutourism. The reason is that the Kindergarten is willing to use edutourism if it is supported by the availability of the budget for edutourism.

\section{Conclusion}

Based on the results of analysis, the average value of the Kindergarten potential market willingness to pay for oyster mushroom edutourism is IDR 21,923.00 per student. The company can use the estimated average value of the survey on potential market willingness to pay as the reference to determine the tariff. The edutourism value based on the total estimation of the survey on the willingness to pay is IDR $40,842,549.00$. The company will be able to generate this value if they set the tariff based on the survey on potential market willingness to pay.

Meanwhile, the factors affecting the potential market willingness are the educational background of the teacher, Educational Management Contribution (SPP), edutourism budget allocation. The potential market with the willingness to pay IDR $21,923.00$ is the Kindergarten where most of the teachers are Undergraduate (S1). The reason is that such Kindergarten tends to have more information related to the edutourism. The second factor is
Educational Management Contribution (SPP). Kindergarten with low Educational Management Contribution category (which is < IDR 60,000.00 per month) has greater willingness due to suitable price and facilities offered by the edutourism. Meanwhile, the Kindergarten with higher Educational Management Contribution (SPP) tends to use edutourism with the higher price and more facilities. The third factor is the edutourism budget allocation. If the Kindergarten has the budget, they tend to be more willing to use edutourism.

The determination of market segmentation is obtained based on the analysis results of logistic regression and descriptive statistics. The results show that Kindergarten with most of the Undergraduate (S1) teachers, low Educational Management Contribution (SPP), and edutourism budget allocation tends to be more willing to use edutourism.

\section{References}

Carson, R. T. (2000). Contingent Valuation: A User's Guide. Environmental Science \& Technology, 34(8), 1413-1418.

Charusiri, W., Tuntates, U., \& Choiejit, R. (2015). Willingness to Pay for Ecotourism Management with Community Participation in Lipe Island, Satun Province. The Asian Conference on Business \& Public Policy Official Conference Proceedings, (2015). 
Foreit, K. G. F., \& Foreit, J. R. (2004). Willingness to Pay Surveys for Setting Prices for Reproductive Health Products and Services: A User's Manual (revised version 2004). Publication on Policy Project.

Gujarati, D. N., \& Porter, D. C. (2009). Basic Econometrics (5th ed.). McGraw-Hill.

Gujarati, D. N., \& Porter, D. C. (2012). Dasardasar Ekonometrika. (D. A. Halim, Ed.) (5th ed.). New York: Salemba Empat.

Hanley, N., \& Spash, C. L. (1993). Cost-Benefit Analysis and the Environment. (E. Elgar, Ed.). UK: Edward Elgar.

Hendayana, R. (2013). Penerapan Metode Regresi Logistik dalam Menganalisis Adopsi Teknologi Pertanian. Informatika Pertanian, 22(1), 1-9.

Hoyos, D., \& Mariel, P. (2010). Contingent Valuation: Past, Present, Future. Prague Economic Papers, 07(April), 329-343.

Nachrowi, N. D., \& Usman, H. (2002). Penggunaan Teknik Ekonometri (1st ed.). Jakarta: Raja Grafindo Persada.

Nasoetion, A. H., \& Barizi. (1980). Metode Statistika. Jakarta: PT. Gramedia.

Ojo, B. Y., \& Yusofu, R. N. R. (2013). Edutourism: International Student's Decision Making Process In Selecting A Host University In Malaysia. European Journal of Business and Management, 5(30), 51-56. Retrieved from http://www.iiste.org/Journals/index.php/EJ BM/article/view/9444

Pearce, D., Atkinson, G., \& Mourato, S. (2006). Cost-Benefit Analysis and The Environtment: Recent Development. Paris: EOCD.

Rezapouraghdam, H., Shahgerdi, A., \& Kahrizi, O. (2015). An Introduction to EduTourism in Northern Cyprus: A Short Communication. International Journal of Sciences: Basic and Applied Research (IJSBAR), 4531, 92-98.

Ritchie, B. W., Carr, N., \& Cooper, C. (2003). Managing Educational Tourism. (C. Cooper, M. Hall, \& D. Timothy, Eds.). Clevedon: Channel View Publication.
Sherri, S. (2017). Educational Tourism is the Best Way to Learn about a Different Culture. Journal Tourism and Hospitality, 6(1).

UNWTO. (2017). Sustained growth in international tourism despite challenges. UNWTO World Tourism Barometer, 15(January).

Williams, R., \& Dame, N. (2017). Marginal Effects for Continous Variables, 1-12. 